\title{
STUDY ON ECONOMIC AND ENVIRONMENTAL BENEFITS OF WASTE BANK INITIATIVES IN DKI JAKARTA PROVINCE
}

\author{
Renny Nurhasana ${ }^{1}$, Victor S. Muhandiki ${ }^{2}$ \\ ${ }^{1}$ Faculty of Public Health, University of Indonesia, Indonesia ${ }^{2}$ School of Engineering, Nagoya \\ University, Japan \\ Email: renny.nurhasana@yahoo.com
}

\begin{abstract}
The aim of this study was to measure economic and environmental benefits, and also sustainability of Waste Bank in DKI Jakarta by conducting a field survey. The study found that Waste Bank activities have generated approximately IDR 11,628,433 (USD 1,199) of additional income to their members. The Waste Bank activities have also contributed to the reduction of waste volume by almost 4.55 tons or $15.2 \mathrm{~m}^{3} \mathrm{per}$ month that equals to saving IDR 16,750,512/year (USD 1,727) of transportation cost and tipping fee. If the Waste Bank initiative can be scaled up to $5 \%$ of total households in Jakarta, the total economic benefits would be about IDR 17.27 billion (USD 1,78 million). As a social business, Waste Banks have also produced environmental benefits by increasing community awareness on 3Rs, thus, improving social cohesion and empowering society. In terms of sustainability, most Waste Banks are both financially and socially sustainable as business entities. While the economic benefits are relatively small, the environmental benefits are significant to the society.
\end{abstract}

Keywords: Economic Benefit, Environmental Benefit, Jakarta - Indonesia, Social Business, Waste Bank.
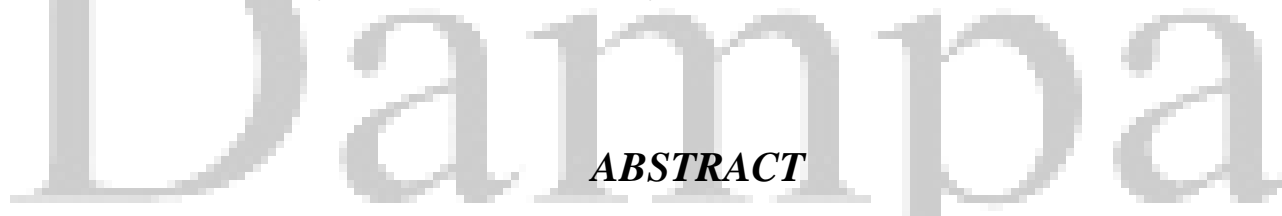

Tujuan dari penelitian ini adalah untuk mengukur manfaat ekonomi dan lingkungan serta kesinambungan dari Bank Sampah di DKI Jakarta melalui data yang didapat dari survei lapangan. Penelitian menemukan bahwa aktifitas Bank Sampah menghasilkan Rp. 11.628 .433 (USD 1,199) penghasilan tambahan untuk anggotanya. Bank Sampah juga berkontribusi terhadap pengurangan jumlah sampah sampai dengan 4,55 ton atau 15,2 $\mathrm{m}^{3}$ per bulan yang sama dengan menghemat Rp. 16.750.512/tahun (USD 1,727) dari biaya transportasi dan biaya tips dari pembuangan sampah di tempat pembuangan sampah akhir. Jika Bank Sampah dapat diperluas hingga 5\% dari keseluruhan rumah tangga di Jakarta, total manfaat ekonomi akan menjadi Rp. 17,27 milyar (USD 1,78 million). Sebagai bisnis yang bergerak dalam lingkup sosial, Bank Sampah juga menghasilkan manfaat lingkungan dengan menaikkan kesadaran masyarakat terhadap $3 R$ selain juga memperbaiki kohesi sosial dan pemberdayaan masyarakat. Dalam area kesinambungan, mayoritas Bank Sampah akan sinambung baik dalam hal keuangan sebagai entitas bisnis sosial. Jika dalam manfaat ekonomi Bank Sampah relatif rendah, manfaat lingkungan yang dihasilkan signifikan terhadap masyarakat.

Kata kunci: Manfaat Ekonomi, Manfaat Lingkungan, Jakarta - Indonesia, Bisnis Sosial, Bank Sampah. 


\section{INTRODUCTION}

The current Municipal Solid Waste (MSW) management service provided by the Jakarta government is by a conventional "collecttransport-dispose" method. The average collection rate in Jakarta is approximately $80 \%$ of the generated amount. The remaining wastes are conventionally burned or remain uncollected on public streets, rivers, and other public places (Nurhasana et al., 2011). In order to reduce waste generation in the city, a 3Rs (reduce, reuse and recycle) program is necessary and important. The $3 R$ s program helps the government in the current system to reduce transported waste to landfill by up to 485 ton/day, which is around $7 \%$ of the total waste generation (Cleaning Department of Jakarta, 2010 in Aprillia et al., 2011).

There are two feasible options for improving the recycling rate in Jakarta, namely: 1) 'Single top-down approach' from the government to community by strengthening regulations and law enforcement; and 2) Community participation in the solid waste management. Lack of financial budget, human capacity and law enforcement are major obstacles to choosing the first option. The second option can be a feasible alternative to be implemented in Jakarta. The Waste Bank, currently practiced by some communities in Jakarta, is one of the good examples of community participation in the solid waste management in Jakarta.

In June 2008, the first concept of Waste Bank was introduced in Indonesia. In this case, people are required to do the process of sorting the waste first, and then deposit it to the bank; in turn, they receive some money which is directly put into their savings (Suwerda and Yamtana, 2009). The concept of Waste Bank imitates the idea of the monetary bank, but the deposit is not money but recyclables. Customers separate the waste at the source and the recyclable waste is deposited to the bank. However, only waste with economic value can be deposited in the bank. The bank then re-sells recyclable waste to recycling companies for profit gains. Waste Bank is not only profit oriented but also has a role to educate the community, promote waste separation, increase the recycling rate and also reduce the budget for waste transportation and tipping fee for waste disposal to landfill (Nurhasana et al., 2011; Sidik, 2012). To establish the successful Waste Bank, Ministry of Environment had formulated key success factors including leaders commitment and capacity in government sectors, community participation, financing, data and information support, and the regulations itself (PermenLH No.13, 2012).

The Waste Bank as a new type of social business is perceived to be one solution to waste management in Jakarta but it is not yet evaluated in terms of both benefits and sustainability. This study, therefore, aims at measuring the economic and environmental benefits of Waste Banks in DKI Jakarta. There are four research questions: 1) What are the contributions of Waste Bank on reducing the waste volume?; 2) How much are the economic benefits produced by Waste Bank initiatives?; 3) What are the environmental benefits created by Waste Bank?; 4) Is the Waste Bank sustainable as a business entity? The comprehensive analysis of Waste Bank initiatives undertaken in this study will help stakeholders to improve the role of Waste Bank on MSW management in Jakarta. This analysis will also facilitate other cities or communities to replicate and scale up Waste Bank initiatives.

The next section focuses on literature review of the solid waste management both in DKI Jakarta and the concept of Waste Bank initiatives. Section 3 presents the research methodology, and the analytical framework of measuring economic benefits, environmental benefits, and the sustainability. Section 4 analyses the outcome of economic benefits, environmental benefits and the sustainability of Waste Banks. The last section summarizes the main findings and discusses their policy implications.

\section{Waste Bank Initiatives}

\section{The First Waste Bank Initiatives}

In 1997, the first "garbage for egg" project was initiated in Klong Toey Slum, Bangkok and was proclaimed to be among the first community based recycling projects. Starting from the waste exchange project in Klong Toey Slum, Bangkok, the recycling 
bank approach has been developed on the basis of public participation. Instead of exchanging recyclable materials with eggs or other consumer products, the recycling bank pays the recyclers in cash or credit depending on the administration procedure (Singhirunnusorn et al., 2012). Around 500 Waste Banks in Thailand collect 18,000 30,000 tons of waste per year (Sasaki, 2006).

In June 2008, the first concept of Waste Bank was introduced in Bantul, Yogyakarta Province, Indonesia. In this case people sort waste, deposit it to the bank, and receive some money which is directly put into their savings (Suwerda and Yamtana, 2009). In 2008, the Unilever Indonesia Foundation started an annual competition called Jakarta Green and Clean in which Waste Bank initiatives and community empowerment were two important assessment criteria (Nurhasana et al., 2011). Twenty-five Waste Banks were developed in DKI Jakarta Province under Unilever Indonesia Foundation Environment Program. In May 2010, Bina Mandiri Waste Bank in Surabaya, East Java Province was established by university students in partnership with an electricity company (PT. PLN East Java). Such Waste Bank initiatives are social businesses which are not purely profit oriented, but also have social responsibilities to the community such as waste reduction, charities, community empowerment through job opportunities and waste education services. In East Java Province, the first city level Waste Bank called "Malang Waste Bank" was established in 2011.

\section{Waste Bank as a Social Business}

Yunus (2009) defined "Social Business" as a non-loss, non-dividend company designed to address a social objective within the highly regulated marketplace today. A social business is different from a non-profit entity because the business should generate a modest profit to be used to expand the company's reach, improve the product or service or in other ways to subsidize the social mission. In this context, a social business would operate like a profitmaximizing business in that the company must financially gain profits to cover all costs but at the same time achieve the social objective. Therefore, profit or revenue is an indicator of sustainability of the company. Waste Bank can be categorized as one of the social businesses that are dealing with environmental issues. Both administrators and members of Waste Bank collaborate with each other to operate the Waste Bank under a non-profit maximizing behavior.

\section{METHODOLOGY}

\section{Measuring of Economic and Environmental Benefits}

In this study the evaluation of Waste Bank initiatives focused on three main issues: economic benefits, environmental benefits, and business sustainability. If Waste Bank can significantly create economic and environmental benefits and also can be sustainable as a social business entity, then the Waste Bank can be scaled up and be promoted as one of the best solutions of solid waste management problems in Jakarta and other big cities in Indonesia. To expand Waste Bank within the cities needs various supports from government and community as well as other parties support such as private sectors. The most important is the commitment and capacity of government to integrate Waste Bank.

Fig. 1 provides the analytical framework of measuring economic and environmental benefits of Waste Bank while Fig. 2 provides the analytical framework for assessing Waste Bank sustainability. Fig. 1 shows the benefits of Waste Bank divided into two parts: economic benefits (direct benefits) and environmental benefits (indirect benefits) (Walo et al., 1996). The indicators used for measuring economic benefits are income generation received by Waste Bank members and the reduction in an amount of waste disposed to landfill.

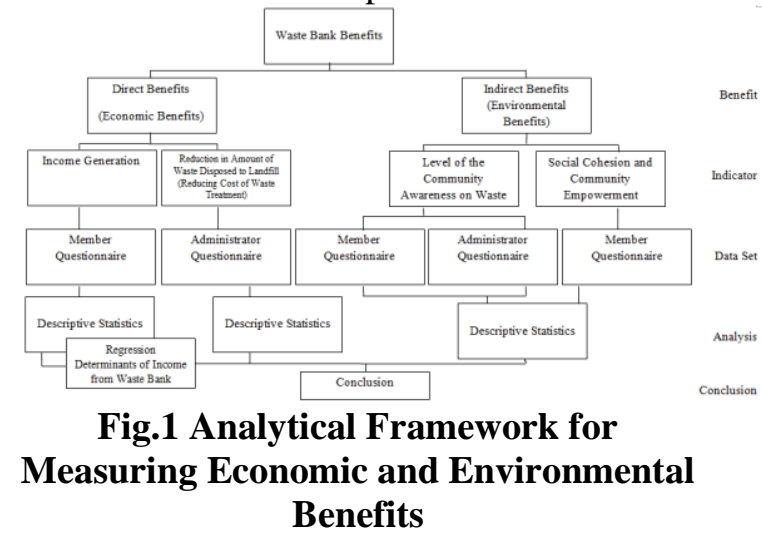


In terms of indirect benefits, this study only focuses on environmental benefits resulting from Waste Bank activities. Indicators applied to evaluate these benefits include community awareness on $3 \mathrm{Rs}$ issue, and social cohesion and community empowerment. Cheung and Leung (2011) pointed out that social cohesion within a neighborhood, which refers to harmonious interactions and mutual support among residents, is integral to the social sustainability of the neighborhood and results in residents' satisfaction with life. Roy (2010) defines and evaluates empowerment as either some social, political, or economic end-product of a specific event. Empowerment or local autonomy represents people's control over the social production in places in which they live and work (Lake, 1994 in Roy, 2010). Whereas, empowerment can be an activity to produce income at each household from exchanging recyclables and an autonomy of managing and separating waste. The reduction in amount of waste disposed to landfill can also be viewed as an indicator of creating an environmental benefit. Recycling program has a positive impact on the environment through the saving of resources and reduction in the impacts from landfill such as greenhouse gas and landfill savings.

This study also employs regression analysis to find out determinants of member income resulting from Waste Bank activities. This will facilitate evaluation of factors that influence most on additional income of members from the Waste Bank. Thus, we can know how to increase the additional income of Waste Bank members.

\section{Measuring of Sustainability}

The sustainability of Waste Bank as a business entity is a main concern of stakeholders. If Waste Bank is sustainable, then the Waste Bank can be one of the major initiatives for solid waste management in cities with government support. In this case, Waste Bank act as an initiative comply with government regulation as a formal social business. The sustainability consists of three pillars: economic, social and environment. Economic sustainability is defined here as the ability of an economy to support a defined level of economic production indefinitely. Social sustainability is defined as the ability of a social system, such as a country, family or organization, to function at a defined level of social well-being and harmony indefinitely. Meanwhile, environmental sustainability is defined as the ability of environment to support a defined level of environmental quality and natural resource extraction rates indefinitely.

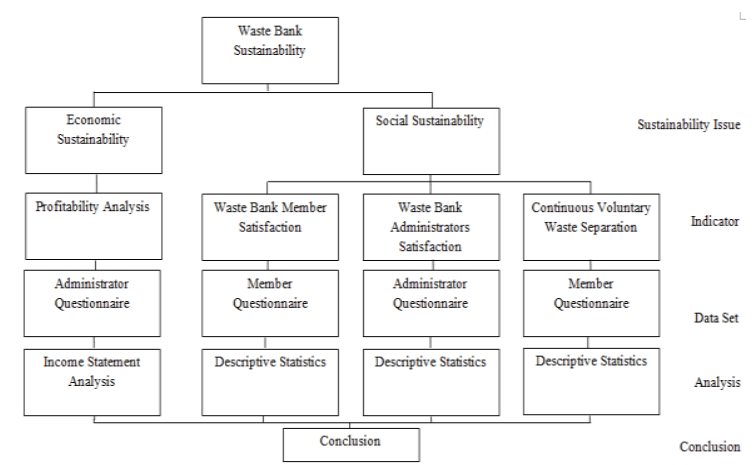

Fig. 2 Analytical Framework for Measuring Sustainability

Fig. 2 shows the analytical framework for evaluation of Waste Bank sustainability. The sustainability of Waste Bank focuses on two pillars: economic sustainability and social sustainability. The economic sustainability involves using assorted assets of the company efficiently to allow it to continue functioning profitability over time. Thus, the Waste Bank activities as a business entity are sustainable, if they can produce operational profit or at least they can finance operating costs of Waste Bank. The measurement of the economic sustainability of Waste Bank is done using mainly the income statement of Waste Bank. As a complement, the satisfaction of Waste Bank members is used as an indicator of social sustainability. The higher the satisfaction of members, the higher the indication that the member will continuously support or maintain the operation of Waste Bank. On the other hand, social sustainability can be achieved when the society (both Waste Bank members and administrators) can mutually collaborate in operating Waste Banks. Thus, high willingness to separate waste is a good indicator that the Waste Bank could be maintained in the long run. 


\section{Data Collection}

The study undertook a questionnaire survey in February 2012 on selected Waste Banks in DKI Jakarta that are affiliated with the partnership program initiated by the Unilever Indonesia Foundation. Two types of questionnaires were distributed: Waste Bank's member questionnaire and Waste Bank's operator questionnaire. There are 25 Waste Banks that have been established in five municipalities of DKI Jakarta Province under cooperation among the Local Government, Unilever Indonesia Foundation and the Local Community. Twenty two (22) Waste Banks established during 2008-2011 were selected as sample size in this research. The number of respondents (Waste Bank member) was selected proportionally depending on the year of establishment and the number of total Waste Bank members. The maximum number of respondents for each Waste Bank was $10 \%$ of total number of the members. The selected respondents for each Waste Bank varied from 1 to 12 respondents. Respondents were selected semi-randomly in the day of survey when they were depositing the waste at the Waste Bank. In total, 119 respondents of Waste Bank members and 22 respondents of Waste Bank administrators were interviewed in the survey.

\section{RESULTS AND ANALYSIS}

\section{Economic Benefits}

\section{Income Generation}

An increase in income of Waste Bank member generated from transaction of recyclables is the first indicator of economic benefits. The increase in income (money) can be viewed as the direct benefit received by Waste Bank members. The monetary value of recyclables is a product of multiplication of the market price of recyclables and the amount of recyclables. In early 2011, the average monthly monetary value of recyclables deposited to the bank was relatively small, around IDR 3,400 [USD 35 cents (USD $1=$ IDR 9,700)] but the value is continuously increasing. There are two possible reasons why there is significant increase of deposited recyclables: 1) waste separation skill is improving (learning by doing process), and 2) members change of perception that waste has an economic value.

In the early stage of joining the Waste Bank, members might be confused or be unfamiliar with the separation of wastes into recyclables and non-recyclables. Thus, some members could only deposit a small amount of recyclables. Learning by doing process of separating wastes in daily activities results in a better understanding of waste separation by Waste Bank members. As a result, the amount of deposited recyclables increased gradually. Further, becoming a member of Waste Banks may also change people's perception from waste has no economic value to waste can give additional income. A change of perception makes members to carefully separate recyclables from nonrecyclables and to actively deposit recyclables to the bank in order to get more additional income.

The total amount of deposit in 2011 for the surveyed members was IDR 11,628,433 (USD 1,199) or on average each Waste Bank member had savings of around IDR 104,760 (USD 10.8). During 2011, 32 members withdrew IDR 2,695,500 (USD 278) of their savings. Thus, total Waste Bank transaction of 111 members was IDR 14,323,933 (USD 1,477 ) or IDR 129,044 (USD 13.3)/member. By aggregating total deposit and total saving withdrawn of all surveyed Waste Banks, the total turnover of Waste Bank activities in Jakarta can be estimated. There are 1,675 members of 22 Waste Banks, thus, the total turnover of Waste Bank is around IDR 216,149,439 (USD 22,283) (1,675 members x @ IDR 129,044) if other Waste Bank members are as active as the surveyed members. Following the increasing trend of deposited recyclables, the turnover of Waste Bank is projected to be twofold in 2012.

\section{Reduction in Amount of Waste Disposed to Landfill}

Other economic benefits of Waste Bank can be also measured using the cost saving in transporting and disposing waste to landfill. Waste Bank activities reduce the waste volume, thus, they reduce the government's burden to transport and dispose off waste to the landfill. There are two cost components of disposing off waste to the landfill: 
transportation cost and tipping fee. Table 1 provides information of volume of collected recyclable waste. This information was the basis of calculating cost saving. From 22 Waste Banks, 17 Waste Banks have a complete record of sales transactions and volume of recyclable waste for 2011. The volume of waste resold by administrators of Waste Banks is equivalent to the volume of waste that is not disposed to landfill. In a month, Waste Banks can reduce the volume of waste by about 4.55 ton or $15.2 \mathrm{~m}^{3}(4.55$ ton $/ 0.3$ ton $/ \mathrm{m}^{3}$ ).

Table 1 Calculation of Waste Transportation Cost and Tipping Fee Saving

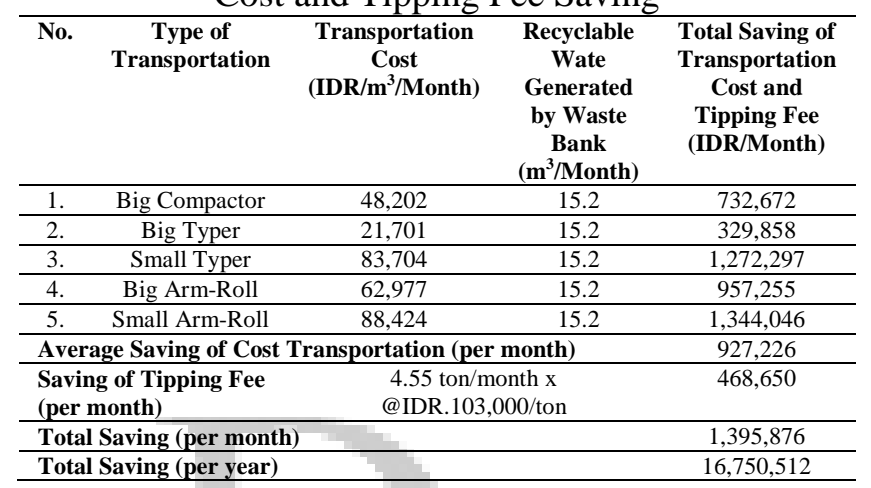

Source: Authors' Calculation based on 2007 Standard Operational Procedure Cleaning Department of Jakarta Final Report

Table 1 also provides information of calculating the saved costs of transportation and tipping fee. Transportation cost saving varies depending on the type of transportation used. Taking an average of the transportation cost, Waste Banks can save the transportation cost by IDR 927,226/month (USD 95.6). In terms of tipping fee, The Cleaning Department of DKI Jakarta pays IDR 103,000 (USD 10.6)/ton of the tipping fee to the landfill's regulator. This fee is used for the further treatment of disposed waste. The saved tipping fee is IDR 468,650 (USD 48.3)/month (IDR $103,000 \times 4.55$ ton permonth). Adding the saved transportation cost and the saved tipping fee gives IDR 16,750,512 (USD 1,727)/year. This amount is the contribution of Waste Banks on reducing the fiscal burden of DKI Jakarta government on treating waste.

This contribution is relatively small compared to the overall cost of solid waste management in DKI Jakarta Province.
However, in the long run, looking at the Waste Bank initiative comprehensively (both direct and indirect benefit), the contribution of Waste Bank on reducing the government burden and on generating income is significant. The total economic benefits of Waste Bank are approximately IDR 232,899,951 (USD 24,010) consisting of member additional income IDR 216,149,439 (USD 22,283.45) and waste transportation saving costs IDR 16,750,512 (USD 1,726.86) in 2011.

\section{Projection of Economic Benefits of Waste Bank Initiative}

As mentioned above that the turnover of Waste Bank is projected to be twofold in 2012 due to the increasing trend of deposited recyclables, the economic benefits of Waste Banks can likewise increase significantly in the future. This study tries to estimate the future economic benefits of Waste Banks using the extrapolation method. The extrapolation method calculates the future economic benefits by weighing the current economic benefits with the number of households in Jakarta. The results of projection of economic benefits represent the condition when the Waste Bank initiative widens (scales up) all over DKI Jakarta.

Table 2 shows the projection of economic benefits of Waste Bank under different scenarios of scaling up of Waste Bank. The current Waste Bank members represent only $0.067 \%$ of total households in DKI Jakarta. The Waste Bank has a high potential when scaled up all over DKI Jakarta. If the Waste Bank initiative can cover $1 \%$ of total household in Jakarta, the total economic benefits will be IDR 3.45 billion (USD $356,000)$ coming from IDR 3.2 billion of additional income and IDR 248 million of total saving. With extra efforts of all stakeholders to share and popularize credible information of Waste Bank, this initiative can cover around $5 \%$ of total household in DKI Jakarta. If it happens, then the economic benefits of Waste Bank can reach IDR 17.27 billion (USD 1.78 million) consisting of IDR 16.03 billion of additional income received by households and IDR 1.24 billion of total saving of transportation cost and tipping fee received by the government of DKI Jakarta. The saved 
transportation costs and tipping fee equal to $0.17 \%$ (IDR 1.24 billion/IDR 740 billion) of total budget of Cleaning Department in
2011. Furthermore, 5\% widening of Waste Bank in Jakarta can reduce the volume of waste by around $13,500 \mathrm{~m}^{3} /$ year.

Table 2 The Projection of Economic Benefits of Waste Bank under Different Scenarios of

\begin{tabular}{|c|c|c|c|c|c|c|c|}
\hline \multirow[t]{2}{*}{ Economic Benefits } & \multirow{2}{*}{$\begin{array}{c}\text { Existing } \\
\text { Condition (000 } \\
\text { IDR/member } / \mathbf{y} \\
\text { ear) }\end{array}$} & \multicolumn{6}{|c|}{$\begin{array}{c}\text { Simulation Scenarios of Scaling Up of Waste Bank Initiative } \\
(\% \text { of Total Household (HH)) }\end{array}$} \\
\hline & & $\begin{array}{c}1 \% \text { of } \mathrm{HH} \\
(24,841)\end{array}$ & $\begin{array}{l}2,5 \% \text { of } \mathrm{HH} \\
(62,103)\end{array}$ & $\begin{array}{c}5 \% \text { of } \mathrm{HH} \\
(124,205)\end{array}$ & $\begin{array}{c}10 \% \text { of } \mathrm{HH} \\
(248,410)\end{array}$ & $\begin{array}{c}15 \% \text { of } \mathrm{HH} \\
(372,615)\end{array}$ & $\begin{array}{c}20 \% \text { of } \mathrm{HH} \\
(496,821)\end{array}$ \\
\hline Additional Income of & 129 & $3,205,586$ & $8,013,965$ & $16,027,929$ & $32,055,859$ & $48,083,788$ & $64,111,718$ \\
\hline Member (Household)(a) & 13.30 & 330,473 & 826,182 & $1,652,364$ & $3,304,728$ & $4,957,092$ & $6,609,455$ \\
\hline Total Saving of & 10 & 248,410 & 621,026 & $1,242,052$ & $2,484,103$ & $3,726,155$ & $4,968,206$ \\
\hline $\begin{array}{l}\text { Transportation Cost and } \\
\text { Tipping Fee (b) }\end{array}$ & 1.03 & 25,609 & 64,023 & 128,047 & 256,093 & 384,140 & 512,186 \\
\hline $\begin{array}{l}\text { The Reduce in the } \\
\text { Volume of Waste } \\
\text { ( } \mathrm{m}^{3} / \text { year) }\end{array}$ & 0.109 & 2,708 & 6,769 & 13,538 & 27,077 & 40,615 & \\
\hline $\begin{array}{l}\text { Total Economic } \\
\text { Benefits }(\mathbf{a}+\mathbf{b})\end{array}$ & $\begin{array}{l}139 \\
14,33\end{array}$ & $\begin{array}{l}3,453,996 \\
356,082\end{array}$ & $\begin{array}{l}8,634,990 \\
890,205\end{array}$ & $\begin{array}{l}17,269,981 \\
1,780,410\end{array}$ & $\begin{array}{l}34,539,962 \\
3,560,821\end{array}$ & $\begin{array}{l}51,809,943 \\
5,341,231\end{array}$ & $\begin{array}{l}\text { 69,079,924 } \\
7,121,642\end{array}$ \\
\hline
\end{tabular}

Note: According to the 2010 population census, the number of households in DKI Jakarta in 2010 was 2,484,103. The figures in italic are the values in USD. The calculation assumes that one member of Waste Bank equals to one household. A 5\% scaling up of Waste Banks is the most feasible scenario since currently Waste Banks only cover $0.067 \%$ of households in Jakarta.

Source: Authors' Calculation

\section{Environmental Benefits}

Environmental benefits from Waste Bank initiatives can be categorized as indirect benefits which cannot be easily quantified in monetary value. This study divided the environmental benefits into: community awareness on waste education, and social cohesion and community empowerment.

\section{Community Awareness of 3Rs Activities}

Waste Bank has contributed to environmental education of members by conducting 3Rs awareness program. The program is not only limited to explanation of 3Rs but also other waste education related to solid waste management. Waste Bank conducts the waste education program in cooperation with other community organizations such as the community itself, youth members, housewife organizations, non-governmental organizations, schools and the private sector. The 3Rs campaign activities involving broader stakeholders are expected to increase the awareness significantly. Results of the member questionnaire survey showed that $52 \%$ of respondents knew the acronyms and meaning of 3Rs while only $24 \%$ of respondents still do not understand the definition and the meaning of "3Rs". The knowledge of $3 R$ s is important in Waste Bank activities since informed Waste Bank members can properly separate recyclable waste which can be deposited to the Waste Bank.

Even though waste is part of daily activities and habits, the 3Rs campaign and the explanation of Waste Bank activities can change the mindset of the community with respect to waste. First, waste is not just "waste" but has an economic value (income generation) if it is separated into recyclable waste and non-recyclable waste. Second, recycling activities can improve the quality of environment in the long run and also benefit the quality of life. Third, the improvement of social cohesion and the empowerment of society may occur through activities within the Waste Bank.

As mentioned before the Waste Bank is one kind of social business; therefore, the main purpose of establishing the bank should not only be based on economic consideration but also on environmental consideration. Almost $87 \%$ of Waste Bank members said that the environmental reason (loving earth) is the main reason of joining the Waste Bank while only $4 \%$ of respondents consider the economic reason (additional income) as the reason of joining the bank. Around 7\% of 
Waste Bank members joined the bank for building social cohesion. These findings indicate that community participation on solid waste management by establishing and joining the Waste Bank is dominated by environmental consideration as opposed to the economic incentives. These findings can also explain why the economic benefit generated by Waste Bank activities is relatively small. This is because people separate and deposit waste not for the maximization of the profit or economic benefit, but mainly for environmental reason.

\section{Social Cohesion and Community Empowerment}

Waste Bank initiatives are expected to increase the social cohesion in the community. In the urban area where individualistic and transactional behaviors dominate daily life activities, as human beings, people would like to have closer relationship in their neighborhood. Closer relationship will increase the quality of life by increasing awareness, deterring crime, and encouraging supporting and helping each other. Joining Waste Bank has increased social cohesion and harmony within neighbors according to $96 \%$ of the respondents of the questionnaire survey to Waste Banks members. Social cohesion and harmony are a result of member interactions when they deposit recyclables to the bank. Meeting and talking can create a mutual understanding among neighbors and then, in the long run, social cohesion and harmony among society can be build.

The other important role of Waste Bank is women empowerment. Since most of the members are housewives with the main responsibility of managing domestic works in their households, joining Waste Bank provides them with opportunities to increase their knowledge of 3Rs and also create additional income. Members may feel that they can contribute in saving the earth and earn additional income by separating and depositing recyclable to the bank. Being empowered makes housewives become more self-confident and not in subordinate to men. Even though the additional income from Waste Bank activities is relatively small, housewives can still feel that they are contributing to household income. Almost $85 \%$ of Waste Bank members surveyed noted that they had been empowered by joining the Bank.

\section{Sustainability of Waste Bank Initiative}

\section{Economic Sustainability}

Sustainability is now frequently understood to be a combination of environmental, social and economic performance. Economic sustainability is the most elusive component of the triple bottom line. Waste Bank is not a purely business oriented entity, bringing social and environmental objectives; Waste Bank should be also a non-loss entity and economically sustainable. Thus, Waste Banks should finance operational activities, expand business, improve product delivery and subsidize social missions.

In the economic and business literature, a business can stay at the market (sustainable) if it can cover expenses for running the business. Therefore, Waste Bank should be managed in a way that, expenses should not exceed revenue, thus sustainable as a business entity. The income statement of 12 Waste Banks (out of all the 22 Waste Banks surveyed) that had good book keeping in 2011 show that total sales were IDR 74 million (USD 7,656) while total expenditures were IDR 52.7 million (USD 5,436). All of these 12 Waste Banks except the one had a positive profit, meaning that total expenditure was less than total revenue. This indicates that Waste Banks in Jakarta are economically sustainable as a social business.

Four of the 12 Waste Banks (33\%) were very active in transacting recyclables as shown by the 2011 total sales of more than IDR 10 million, while two Waste Banks (17\%) had low sales of less than IDR 1 million. The rest of the Waste Banks (50\%) can be categorized as ordinary Waste Banks. Even though inactive Waste Banks are not so active in transactions, currently they are profitable. However, in the future, these Waste Banks may not continue their operation due to low transactions and discouragement. In contrast, ordinary Waste Banks can grow to active Waste Banks if there are some interventions such as training 
of Waste Bank administrators, more campaigns and training for members and other incentives.

\section{Social Sustainability}

Most (86\%) Waste Bank members are satisfied with the money received from depositing recyclables on the Waste Bank while $85 \%$ of them also are satisfied with the performance of their Waste Banks. Even though the money received is relatively small, they are satisfied with it since wastes that previously had no economic value are converted into money after joining the Waste Bank. Most Waste Bank members reported that they are satisfied with the Waste Bank, and they may continuously support the operation of Waste Banks by depositing recyclables continuously.

Most Waste Bank members (89\%) reported that they voluntarily continue to separate waste even without monetary incentives. This indicates two important things: 1) Waste Banks successfully taught members the importance of waste separation; 2) A small monetary incentive or other incentive may attract Waste Bank members to actively separate and deposit recyclables into the Waste Bank since without any incentives they still want to separate wastes.

\section{Factors Affecting Amount of Deposit to Waste Bank}

This section employs regression analysis to find out the determinants of additional income (amount of deposit) of members from Waste Bank deposits. This helps us to evaluate the important factors that most influence the additional income from Waste Bank activities. Thus, we can know how to increase the additional income to the member of Waste Bank. The econometric model (Eq.1) is shown below:

$$
y_{i}=\beta_{0}+\beta_{1} 3 R K_{i}+\beta_{2} \text { age }_{i}+\beta_{3} \text { lexart }_{i}+\beta_{4} \text { price }_{i}+\beta_{5} \text { envi }_{i}+\varepsilon_{i}
$$

Where, $y$ is the amount of deposit (additional income); $3 R K$ is the knowledge of $3 \mathrm{Rs}$ (reduce, reuse and recycle); age is the age of respondent; lexart is log expenditure per capita; price is price satisfaction; envi is the environmental reason of joining Waste Bank, $\varepsilon$ is the error term; $i$ is the respondent. The econometric model is estimated using OLS (Ordinary Least Square) method (Wooldridge, 2010).

Table 3 shows the estimation result of Eq.1. The model can statistically explain the behavior of dependent variable that is shown by Prob (F-Statistic) less than 1\%. Among five explanatory variables, only two important variables (dummy of 3Rs knowledge and age of respondent) significantly influence the amount of deposit (additional income). If the Waste Bank members fully understood the meaning of 3Rs, then the log amount of deposit increases by 0.400 and the members can easily separate recyclables and deposit into Waste Bank. Further, the older people tend to have more deposits than younger ones. This is because the older people may have more understanding about environmental issues or they may have more intention to make the environment clean.

Table 3. Results of Regression Analysis for Determinants of Additional Income

\begin{tabular}{|c|c|c|c|c|}
\hline \multirow[b]{2}{*}{ Variables } & \multicolumn{4}{|c|}{ Dependent Variable: Log Amount of Deposit } \\
\hline & Coefficient & $\begin{array}{l}\text { Robust } \\
\text { Std. Error }\end{array}$ & t-statistic & p-value \\
\hline $\begin{array}{l}\text { Dummy of 3R Knowledge (3RK) } \\
\text { (1= know the 3R meaning; }\end{array}$ & $0.400 * *$ & 0,198 & 2,020 & 0,046 \\
\hline Age of Respondent (age) & $0.034 * * *$ & 0,011 & 3,230 & 0,002 \\
\hline Log Expenditure per-capita (lexart) & $-0,330$ & 0,240 & $-1,380$ & 0,171 \\
\hline $\begin{array}{l}\text { Dummy of Price Satisfaction } \\
\text { (price) } \\
\qquad(1=\text { satisfy with price offered by }\end{array}$ & 0,411 & 0,391 & 1,050 & 0,295 \\
\hline $\begin{array}{l}\text { Dummy of Environmental Reason } \\
\text { (envi) } \\
(1=\text { environmental reason as a }\end{array}$ & 0,112 & 0,218 & 0,510 & 0,608 \\
\hline Intercept & $13.196 * * *$ & 3,190 & 4,140 & 0,000 \\
\hline Number of Observation & & $\mathrm{n}=109$ & & \\
\hline F-Statistic & & 3,66 & & \\
\hline Prob(F-statistic) & & 0,004 & & \\
\hline R-Squared & & 0,111 & & \\
\hline
\end{tabular}

Note: $* *$ and $* * *$ are significant at $5 \%$ and $1 \%$, respectively.

Source: Authors' Estimation 
Even though the magnitudes of coefficients of other explanatory variables fit with the logic, they are not statistically significant. For example, when respondents are satisfied with the price offered by Waste Bank, they tend to have a higher deposit. Rich people represented by the negative log expenditure per-capita coefficient tend to have a low deposit in the Waste Bank. Rich people may think that additional income (amount of deposit) is only petty cash so they may not have much intention to separate and deposit recyclables to the Waste Bank.

\section{CONCLUDING REMARKS}

Waste Bank is an example of community participation on 3Rs activities in Jakarta. The concept of Waste Bank imitates the idea of the monetary bank. This study aimed at measuring economic and environmental benefits, and also sustainability of Waste Bank in DKI Jakarta by conducting a field survey. Results showed that though the economic benefits of Waste Bank received by both Waste Bank members and government are relatively small, the environmental benefits of Waste Bank are significant to increase community awareness on solid waste management and to promote social cohesion and harmony within neighborhoods in Jakarta. Awareness and social cohesion significantly contribute to create a clean environment and a better quality of life in Jakarta. The Waste Bank activities can also change the mindset of the community in viewing waste as not just "waste" but as having an economic value (income generation) when separated to recyclable waste and non-recyclable waste. Looking comprehensively at both direct and indirect benefits of Waste Bank Initiatives, in future, the contribution of Waste Banks to reducing the government's financial burden, generating income and promoting a better quality of life will be significant.

Based to the study results, there are four policy suggestions: 1) Promotion of Waste Banks should focus on raising awareness on issues of environmental and social benefits; 2) Waste Bank administrators should continuously promote/campaign/train members about 3Rs; 3) Waste Bank should be targeted in areas where many older people and middle-low income group live; 4) The DKI Jakarta Province should introduce new incentives to the Waste Banks for example through conducting Waste Bank competitions and promotions or provide additional capital, such as machines or other financial incentives to the Waste Banks.

\section{ACKNOWLEDGEMENT}

We would like to thank Nagoya University Global Environment Leaders Program (NUGELP) and International Epson Scholarship Foundation for study and financial support, Ms. Irma and Ms. Erma for research assistance, all respondents who kindly participated in this research, and Dr. Teguh Dartanto for valuable comments.

\section{REFERENCES}

Aprilia, A., Tezuka, T. and Spaargaren, G. 2011. Municipal Solid Waste Management with Citizen Participation: An Alternative Solution to Waste Problems in Jakarta, Indonesia, Proc. of The Second International Symposium of Global COE Program "Energy Science in the Age of Global Warming-Toward CO2 Zero-Emission Energy - System", Springer Publication, 56.

Cheung, C. and Leung, K. 2011. Neighborhood Homogenity and Cohesion in Sustainable Community Development, Habitat International 35, pp. 564-572.

Cleaning Department of Jakarta, 2007. Standard Operational Procedure of Sanitation in DKI Jakarta Province Final Report, PT. TML Consultant, Jakarta. (in Bahasa Indonesia).

Cleaning Department of Jakarta, 2011. Waste Management in Jakarta, A Presentation Material of Seminar Paradigm of Change in Sanitation Management DKI Jakarta Province, Hotel Millenium, 6 December 2011. (in Bahasa Indonesia).

Cleaning Department of Jakarta 2012. Waste Bank Concept, A Presentation Material of Cleaning Department of Jakarta by Community Participation.

Ministry of Environment. 2012. Regulation No. 13/2012 "Reduce, Reuse, Recycle 
Implementation through Waste Bank".

Nurhasana, R., Muhandiki, V.S., Fitriani, A., Okayama, T. and Susanto, J.P. 2011. Public Private Partnership on Solid Waste Management System: The Case of KWM Delima Waste Bank in Jakarta, Indonesia, Proc. of $2^{\text {nd }}$ Congress of The East Asian Association of Environmental and Resource Economics, Bandung, Indonesia.

Roy, P. 2010. Analyzing Empowerment: An Ongoing Process of Building StateCivil Society Relations-The Case of Walnut Way in Milwaukee, Geoforum 41, pp. 337-348.

Sasaki, S. 2006. Better Practice of Waste Management in Thailand, Proc. of APFED 3Rs Expert Meeting on $5^{\text {th }}$ March, Tokyo, Japan.

Sidik, U.S. 2012. Principles of Solid Waste Management Policy in Indonesia, Ministry of Environment Republic Indonesia's Presentation Material. (in Bahasa Indonesia).
Suwerda, B. and Yamtana. 2009. 'Gemah Ripah', Community Based Waste Bank in Badegan Village, Bantul, D.I. Yogyakarta Province, Jurnal Kesehatan Lingkungan dan Sanitasi, Vol. 2, No. 3, August, pp. 103-107. (in Bahasa Indonesia).

Walo, M., Bull, A. and Breen H. 1996. Achieving Economic Benefits at Local Events: A Case Study of a Local Sports Event, Festival Management \& Event Tourism, Vol. 4, pp. 95-106.

Wooldridge, J.M. 2010. Econometric Analysis of Cross Section and Panel Data, Second Edition, the MIT Press, Cambridge, USA.

Yunus, M. 2009. Creating a World without Poverty: Social Business and the Future of Capitalism, New-York, Public Affairs.

Yunus, M. 2011. Building Social Business: the New Kind of Capitalism that Serves Humanity's Most Pressing Needs, New-York, Public Affairs.

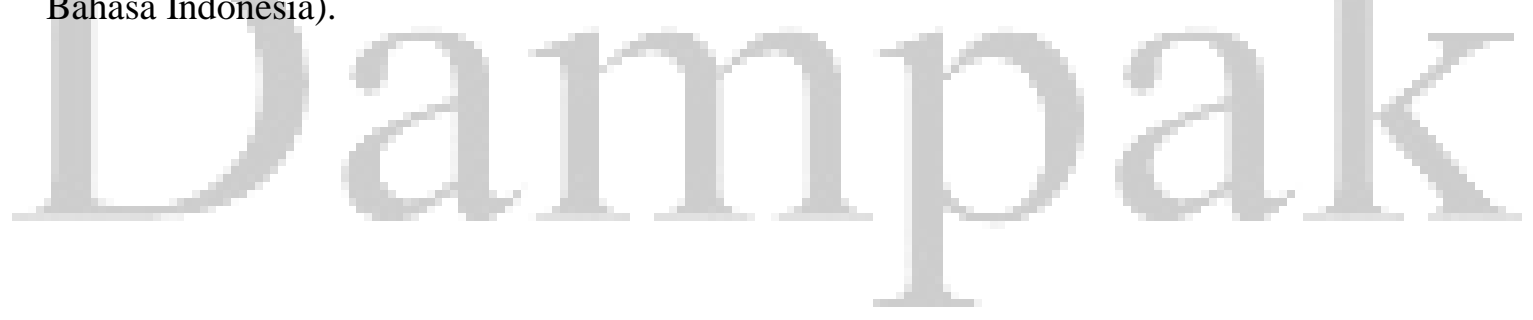

